\title{
How is Chinese English Learners' L2 Metaphoric Competence Related to That of L1? An E-Prime-Based Multi-Dimensional Study
}

\author{
Juanjuan Wang ${ }^{1} \&$ Yi Sun ${ }^{2}$ \\ ${ }^{1}$ School of English Education, Xi' an International Studies University, Xi'an, China \\ ${ }^{2}$ Foreign Linguistics and Applied Linguistics Research Center, Guangdong University of Foreign Studies, \\ Guangzhou, China \\ Correspondence: Yi Sun, Foreign linguistics and Applied Linguistics Research Center, Guangdong University of \\ Foreign Studies, Guangzhou, Baiyun Street North No. 2, China. E-mail: sytony9728@163.com
}

Received: February 8, 2020

Accepted: May 10, 2020

Online Published: May 27, 2020

doi:10.5539/ijel.v10n4p115

URL: https://doi.org/10.5539/ijel.v10n4p115

\begin{abstract}
Even though transfer from L1 to L2 has been repeatedly tested and confirmed, there is little literature and consensus on how and to what extent the L1 metaphoric competence could be related to that of L2. Based on the metaphor acceptability and response time of E-Prime experiments and two written tests of comprehension and production of metaphors on 94 intermediate Chinese-speaking university students of English, this study compares Chinese English learners' similarities and differences in four dimensions (metaphor acceptability, identification speed, metaphor comprehension, and metaphor production) of metaphoric competence between L1 and L2 (here is Chinese and English). The results demonstrate that: Chinese English learners' L1 metaphoric competence is significantly better than that of L2; their L2 metaphoric competence is significantly correlated to that of L1, and the regression analysis shows that L1 metaphoric competence has a significant prediction of that of L2. These findings enlighten us to greatly cultivate metaphoric competence in foreign language teaching and help students create connection between L1 and L2 metaphoric competence. This study also provides statistical support for the claim that metaphoric competence is a general trans-language cognitive ability for Chinese English learners.
\end{abstract}

Keywords: Chinese English learners, L1 metaphoric competence, L2 metaphoric competence, E-Prime experiment

\section{Introduction}

As a hot issue in second language acquisition research, language transfer has already been studied from various aspects like pronunciation, lexicon, syntax, discourse, semantics, pragmatics, and related affecting factors like social environment, cultural background and personal traits, and so on (Odlin, 1989). However, "there has been surprisingly little research into the extent to which language learners are able to transfer their metaphor interpretation and production skills (or behavior patterns) from their mother tongue (L1) to the target language (L2)" (Littlemore, 2010, p. 293). Except for Johnson's (1989) study on Spanish leaners of English mentioned by Littlemore (2010), which found that "the complexity of the interpretations offered in English correlated significantly with the complexity of interpretations offered in Spanish" (Littlemore, 2010, p. 293), we only found 5 other experimental studies on this issue.

The first study is the doctoral dissertation by Azuma (2004), which takes Japanese learners of English as subjects to assess the relationship between L1 and L2's receptive and productive metaphorical abilities. The study showed that the Japanese EFL students' receptive ability was better than their productive ability, and L1 transfer might play an ambivalent role. The second one is by Littlemore (2010), which found French leaners of English displayed a significant correlation between L1 and L2 metaphor competence, but also showed certain differences between two languages. The third one is the study by Bromberek-Dyzman and Ewert (2010), which takes Polish learners of English as subjects to test the differences between L1 and L2's figurative competence in terms of conversational implicature response patterns. The study showed that L2 figurative competence might be similar to that of L1 in certain aspects but at the same time different in other aspects. They urged further research to see "to what extent these assumptions are culturally specific and to what degree they are transferable between languages" (Bromberek-Dyzman \& Ewert, 2010, p. 330). The fourth one is the conference paper by Zamari, 
Adnan, Manan and Pillay (2016), which found that Malay learners of English believed "Malay idioms are significant for both oral and written communication but English idioms are only important for written materials" (ibid, p. 9) and chose familiar Malay idioms for their well-established background knowledge. The last study is done by Birdsell (2018), which compared Japanese English learners' creative metaphoric competence between Japanese and English, and the result suggested that creative metaphoric competence "is an individual difference that underlies one's overall competence" (ibid, p. 35).

We suggest that there is a need to carry out an experimental study of the relationship between L1 and L2's metaphorical competence for Chinese Learners of English for the following reasons. Firstly, no study has been carried out on Chinese learners of English. But as a human cognitive ability, metaphor is claimed to operate beyond language limit (Evans \& Green, 2006; Danesi, 2008; Fauconnier \& Turner, 1998). Although many articles on this issue can be found in Chinese journals, only 6 of them are experimental studies. Shi (2012) and Liu (2012) discussed the influences of Chinese level and English level on metaphor transfer. Yang and Xuan (2012) and Wang and Wang (2019) studied Chinese metaphor transfer in English writing. Ye (2015) focused on the effect of Chinese conceptual transfer ability on English metaphor interpretation. And Jiang and Wu (2017) studied Chinese conceptual transfer in English sentence comprehension. None of the six articles did a multidimensional study on the relationship between L1 and L2's metaphoric competence, and they also ended up with different findings and conclusions. Therefore, we'd like to carry out an experiment-based multidimensional study of the relationship between L1 and L2's metaphorical competence for Chinese Learners of English to provide more evidence from other languages and cultures for metaphoric transfer study. Secondly, many studies confirm that metaphoric competence is facilitating in L2 proficiency development (Evans \& Green, 2006; Andreou \& Galantomos, 2009). And some researchers even tried to develop teaching methods to explore effective ways to enhance transfer of L1 metaphoric competence to L2 (Chen \& Lai, 2015; Bobrova, 2017; Zhang, 2019). Therefore, the present study would tentatively provide theoretical foundation and empirical help for English teaching in China. Thirdly, the existing studies differ in their account of whether, how and to what extent the L1 metaphoric competence could be transferred to L2. Thus, we need a more systematic research on this issue.

Based on the above reasons, we designed an E-Prime experiment of metaphor acceptability and response time and two written tests of comprehension and production of metaphors on 94 intermediate Chinese-speaking university students of English, to compare Chinese English learners' similarities and differences in four dimensions (metaphor acceptability, identification speed, metaphor comprehension, and metaphor production) of metaphoric competence between L1 and L2 (here is Chinese and English). This study is hoped to discuss Chinese English learners' metaphoric competence in a comprehensively multidimensional approach and also to contribute Chinese English learners' data to the metaphoric competence study on different languages.

\section{Literature Review}

The term "metaphoric competence" was firstly coined by Flahive and Carrel (1977), then was furthered by Gardener and Winner (1978) and Pollio and Smith (1980). Later, Danesi (1986) introduced this term into the field of second language acquisition, and claimed metaphoric (conceptual) competence to consist of three subcompetences: metaformal competence (ability to use the conceptual system), reflexive competence (transform concepts into language categories) and associative competence (knowledge of the way abstract concepts are grouped and interrelated together in cultural terms) (Danesi, 2003, pp. 75-76 ). That initiated a hot discussion on language learners' metaphoric competence from different aspects.

One of the focused aspects is to define components of metaphoric competence. Besides Danesi (2003), Low (1988) and Littlemore (2001) also put forward their own understanding of metaphoric competence components. Those detailed components facilitated the integration of metaphoric competence into language teaching methodology and courses. However, the variety of those three claims also brought inconsistence and controversies in researching field. Therefore, we would like to compare those three proposals to summarize their shared components (see Table 1). 
Table 1. Shared metaphoric competence components

\begin{tabular}{|c|c|c|c|c|}
\hline & identification & acceptability & interpretation & production \\
\hline $\begin{array}{l}\text { Low } \\
\text { (1988, pp. 129-135) }\end{array}$ & $\begin{array}{l}\text { knowledge of the } \\
\text { boundaries of } \\
\text { conventional } \\
\text { metaphor }\end{array}$ & $\begin{array}{l}\text { awareness of } \\
\text { acceptable topic and } \\
\text { vehicle combination } \\
\text { and socially sensitive } \\
\text { metaphors }\end{array}$ & $\begin{array}{l}\text { ability to construct plausible } \\
\text { meanings, to interpret and } \\
\text { construct hedges; } \\
\text { awareness of multiple layering in } \\
\text { metaphors }\end{array}$ & $\begin{array}{l}\text { interactive awareness of } \\
\text { metaphor }\end{array}$ \\
\hline $\begin{array}{l}\text { Littlemore } \\
(2001, \text { p. 459) }\end{array}$ & $\begin{array}{l}\text { speed in finding } \\
\text { meaning in } \\
\text { metaphor }\end{array}$ & & $\begin{array}{l}\text { ability to find meaning in } \\
\text { metaphor; fluency of metaphor } \\
\text { interpretation }\end{array}$ & $\begin{array}{l}\text { originality of metaphor } \\
\text { production }\end{array}$ \\
\hline $\begin{array}{l}\text { Danesi } \\
\text { (2003, pp. 75-76) }\end{array}$ & & & $\begin{array}{l}\text { knowledge of the way abstract } \\
\text { concepts is grouped and } \\
\text { interrelated together in cultural } \\
\text { terms }\end{array}$ & $\begin{array}{l}\text { ability to use the } \\
\text { conceptual system; } \\
\text { transform concepts into } \\
\text { language categories }\end{array}$ \\
\hline
\end{tabular}

Table 1 shows that there are 4 shared components among the three proposals: identification, acceptability, interpretation, and production. Identification competence is the ability to recognize metaphor within appropriate time, which covers knowledge of the boundaries of conventional metaphor from Low (1988) and speed in finding meaning in metaphor from Littlemore (2001). That is to say, identification competence not only requires people to recognize metaphorical expressions but also has a requirement on the recognition time, since native speakers would not stop to judge whether the expression is metaphorical or not but would continue naturally even when a metaphorical expression appears. Hoffman and Kemper (1987, p. 152) even claimed that reaction time can unpack the stages or sequences of mental operations of metaphors. Therefore, we believe that recognizing speed is a key factor in identification competence, and will measure learners' recognition time to compare their L1 and L2 identification competence in this study. Acceptability competence is the ability to judge whether the metaphorical expression is appropriate or not, which covers awareness of acceptable topic and vehicle combination and awareness of socially sensitive metaphors from Low (1988). Metaphorical expressions may differ greatly in their acceptability out of vehicle selections and social conventionality. For example, for the concept of strength, "tiger" and "lion" are much more preferred than "elephant", even though "elephant" is much stronger than "tiger" and "lion". Therefore, acceptability competence requires people to find out expressions which are not only metaphorical but also appropriately metaphorical. Interpretation competence and production competence are both covered by the three proposals, which suggests that these two components are essential to metaphoric competence. Therefore, they are also included in our framework. In a word, the framework of metaphoric competence in our present study consists of recognition time, metaphor acceptability, metaphor interpretation and metaphor production.

Another focused aspect is to discover affecting factors on metaphoric competence. Many factors have been proven to affect metaphoric competence like age (Littlemore, 2001), cognitive ability (Johnson, 1989; Johnson \& Rosano, 1993), language proficiency (Martinez, 2003; Wei, 2007), and cultural background (Wang \& Li, 2004). Taken together, learners' factors exert great influence on their metaphoric competence. Therefore, when enrolling experiments subjects, it is important to choose closely equivalent leaners. In section 1, we could find that all the leaners' second language was English, and their English proficiency level was intermediate level. Thus, we intend to enroll Chinese intermediate-level leaners of English as our subjects, to make sure our findings comparable to those in section 1 .

\section{Methodology}

Based on above mentioned reasons and literature, our research aims to study the metaphoric competence of Chinese intermediate-level leaners of English from four subcompetences: recognition speed, acceptability competence, interpretation competence and production competence. In order to get accurate data about the recognition speed, we adopted E-Prime 2.0 to record reaction time when subjects were making choices. E-Prime should display event reaction time in accurate milliseconds to provide reliable access into subjects' recognition process. The following is the details of our research design.

\subsection{Research Questions}

The study is designed to research two questions:

What are the differences between L1 and L2 metaphoric competence in the four subcomponents for Chinese intermediate-level leaners of English? 
To what extent is their L2 metaphoric competence correlated to the L1 metaphoric competence in the four subcomponents?

\subsection{Research Subjects}

We enrolled 94 volunteer Chinese intermediate learners of English at a university in Xi'an. They were all in their second year of a degree in English education. 85 of them were females and 9 of them were males. They all had Chinese as their L1, and English as their L2, and all had passed the TEM 4 (a national test for English majors to indicate their intermediate level). They all had normal naked vision or corrected vision, right-handed, without reading disorder. Before test, they were told by their teachers that they would take part in a research on language learning and signed consent forms.

\subsection{Research Procedure}

In order to get data about the four subcomponents of metaphoric competence, three separate experiments were designed.

\subsubsection{An E-Prime-Based Test on Recognition Speed and Acceptability Competence}

In order to measure their speed to recognize metaphors and acceptability competence, we adapted 30 Chinese metaphorical sentences and their corresponding English ones (all sentences had less than 10 words) from Deignan (2001), Littlemore (2010) and other related studies, and had a pilot test on 94 non-subjects students of similar language level to find out their mostly-familiar 25 Chinese ones and English ones, which guaranteed no unknown metaphors appeared in the formal test. All the chosen 50 sentences and 4 nonsense metaphorical sentences were programmed into E-Prime 2.0. The test was carried out in a language lab with each subject using a computer alone and three experienced experiment assistants in case any problem should happen. Before test, subjects were trained to be familiar with the rubric and the keyboard operation. In the experiment, the computer firstly displayed " + " in the center of the screen for $800 \mathrm{~ms}$, and then displayed the $54(50+4)$ sentences randomly without time control. Subjects should press "Y" if they judged the sentence to be metaphorical as soon as possible and " $\mathrm{N}$ " if not. If a sentence was judged to be metaphorical, it would appear again, and the subjects needed to judge its acceptability on a 1-5 scale (1 for least acceptable and 5 for most acceptable). No one could leave the lab before all subjects had finished the experiment. The average response time and average scores of response to the scale 1-5 for Chinese sentences and English sentences were extracted respectively for further analysis.

\subsubsection{A Written Interpretation Test}

Three major experiment paradigms were adopted in metaphor interpretation study: to give explanations of one metaphor as much as possible, to choose the most appropriate interpretation from given choices and a combination of those two ways (Johnson, 1996; Littlemore, 2010; Liu, 2012; Ye, 2015). Since sometimes none of all the given choices would be accepted by the subjects (Liu, 2012, p. 77), we here adopted the first paradigm. The prerequisite to interpret a metaphor is to recognize and accept the expression. Therefore, we selected the top 5 Chinese sentences and 5 English sentences from the acceptability test as the material in the present interpretation test. Subjects were asked to write down explanations for the ten sentences as much as possible within 40 minutes. One explanation would get 1 score, and the average scores for Chinese and English sentences were calculated respectively for further analysis.

\subsubsection{A Written Production Test}

Two major paradigms were employed to research metaphor production competence: to complete sentences by subjects themselves and to choose the most appropriate completion from given choices (Trosborg, 1985). Birdsell $(2018$, p. 37) pointed out that we could analyze the creative process through creative metaphor production tasks. Therefore, we here adopted the first paradigm to ask subjects to complete 8 Chinese sentences and 8 English sentences in metaphorical expressions as creatively as possible. After the test, we invited 6 experts ( 3 Chinese natives and 3 English natives) in metaphor study to score the expressions in a 1-4 scale (1 for inappropriate expression; 2 for literal expression; 3 for conventional expression; 4 for novel expression). If there was disagreement among the scorers, negotiations would take place to reach an agreement. The average scores of Chinese sentences and English sentences were calculated respectively for further analysis.

\section{Results and Discussion}

After all the three experiments finished, the data for the four subcompetences of Chinese (L1) and English (L2) metaphoric competence were input into IBM SPSS Statistics v20 to be analyzed to answer our research questions. Out of some personal reasons, 3 students did not finish all the tests, so the participants for the final 
date are 91. The results are as follows.

\subsection{Results for Question 1}

Our first question is to find out the differences between L1 and L2 metaphoric competence in the four subcomponents for Chinese intermediate-level leaners of English. Therefore, we made a comparison of the respective average scores as shown in Table 2.

Table 2. Comparisons of L1 and L2' scores on all the four subcompetences $(\mathrm{N}=91)$

\begin{tabular}{lllll}
\hline & speed (ms) & acceptability & interpretation & production \\
\hline Chinese (L1) & 5.941 & 3.2079 & 1.2505 & 2.4538 \\
English (L2) & 8.666 & 3.0580 & 1.1076 & 2.2780 \\
\hline
\end{tabular}

Table 2 shows that students had higher levels of L1 metaphoric competence than that of L2 on all the four subcomponents (for speed, the smaller number indicates a faster speed). We propose that since metaphor involves deep cognitive processing and activation of encyclopedic knowledge as the understanding background, students would perform better in their L1 than in L2, because L1 is more accessible with ease of “meaning-making, comprehension and suitability”(Zamari, Adnan, Manan, \& Pillay, 2016, p. 9).

In order to access the significance of these differences between Chinese and English, we had paired t-tests on all four scores. The results show that these differences are significant. The details are shown in Table 3 below.

Table 3. Paired T-tests of Chinese and English respective scores $(\mathrm{N}=91)$

\begin{tabular}{lll}
\hline & $\mathrm{t}$ & Sig. (two-tailed) \\
\hline CS-ES & -18.138 & .000 \\
CA-EA & 3.975 & .000 \\
CI-EI & 5.277 & .000 \\
CP-EP & 5.514 & .000 \\
\hline
\end{tabular}

Note. CS for Chinese speed; ES for English speed; CA for Chinese acceptability; EA for English acceptability; CI for Chinese interpretation; EI for English interpretation; CP for Chinese production; EP for English production.

Table 3 shows that there are significant differences on the four tests. To be specific, students display the most significant difference in speed in L1 and L2 $(\mathrm{t}(91)=-18.138, \mathrm{p}<0.01)$; then is the metaphor production $(\mathrm{t}(91)$ $=5.514, \mathrm{p}<0.01)$; the third is the metaphor interpretation $(\mathrm{t}(91)=5.277, \mathrm{p}<0.01)$; and the last is the acceptability $(\mathrm{t}(91)=3.975, \mathrm{p}<0.01)$. So, we can conclude that there were statistically significant differences between L1 and L2 metaphoric competence in the four subcomponents for Chinese intermediate-level leaners of English.

\subsection{Results for Question 2}

Our second question is to find out whether their L2 metaphoric competence is correlated to the L1 metaphoric competence in the four subcomponents. Therefore, we carried out a Pearson Correlation Analysis on the scores of all four dimensions, and the results are presented below in Table 4.

Table 4. Correlations between Chinese and English respective scores

\begin{tabular}{llllll}
\hline & ES & EA & EI & EP & Sig. \\
\hline CS & $0.856^{* *}$ & & & & .000 \\
CA & & $0.720^{* *}$ & & & .000 \\
CI & & & $0.698^{* *}$ & & .000 \\
CP & & & & $0.581^{* *}$ & .000 \\
\hline
\end{tabular}

Table 4 shows that scores of four subcompetences in Chinese (L1) are all significantly correlated positively to that of English (L2). To be specific, speed of English metaphor interpretation shows the highest positive correlation with that of Chinese ( $\left.\mathrm{r}(91)=0.856^{* *}, \mathrm{p}<0.01\right)$; then is the metaphoric acceptability $(\mathrm{r}(91)=$ $\left.0.720^{* *}, \mathrm{p}<0.01\right)$; the third is the metaphor interpretation ( $\left.\mathrm{r}(91)=0.698^{* *}, \mathrm{p}<0.01\right)$; the last is novel metaphor production $\left(\mathrm{r}(91)=0.581^{* *}, \mathrm{p}<0.01\right)$. So, we can conclude that Chinese English learners' L2 
metaphoric competence is statistically significantly correlated to the L1 metaphoric competence in the four subcomponents.

\subsection{General Discussion}

The results of question 1 indicate that Chinese students display high levels of metaphoric competence in L1 than in L2 on all four subcomponents. We resort to familiarity and language proficiency for the better results of L1. Since metaphor involves deep cognition, the more familiar L1 metaphors are easier to be accessed by leaners than the unfamiliar L2 ones. This is evidenced by Zamari, Adnan, Manan and Pillay's (2016, p. 9) finding that students would choose L1 idioms other than L2 ones due to "familiarity". Besides, many studies have shown the influence of second language proficiency on metaphor ability (Hoang \& Boers, 2018; Galantomos, 2019). Generally speaking, students have a higher language proficiency in L1 than in L2. Thus, they would perform better on metaphoric tests in L1 than in L2.

The results of question 2 indicate that there is a strong correlation between L1 and L2 metaphoric competence which is in line with Littlemore's (2010) finding. That is to say, students who have a high level of metaphoric competence in L1 are more likely to display a high level of metaphoric competence in L2. This confirms Birdsell's (2018, p. 35) finding that creative metaphoric ability "is an individual difference that underlies one's overall linguistic competence". This finding holds an important enlightenment for foreign language teaching. Kathpalia and Carmel (2011) argues that metaphoric ability is "the mark of a fluent second language user". Galantomos $(2019$, p. 1) also found "a differentiation across language levels with respect to the ability to use metaphors" and suggested the highlighting of "the place of metaphoric competence in L2 pedagogy". Therefore, we should encourage teaching and fostering of metaphoric competence in our teaching of English as a second or foreign language. Since we are now certain about the strong positive correlation between L1 and L2 metaphoric competence, we can permit L1 as a teaching medium to facilitate transfer of metaphoric competence from L1 to L2, and L2 teaching programs are to be designed in reference to "prior linguistic knowledge and learning experience as a cognitive basis for additional language learning" (Haim, 2015, p. 711). This teaching method agrees with the "holistic" notion of multilingualism (Cook, 2013) and current trend of bi/multilingual education by García and Li Wei (2014).

Our results also indicate that metaphoric competence is a general cognitive process beyond language limit. Strapparava $(2018$, p. 1) emphasizes the nature of metaphor as "a means of human communication" and "a necessity of our mind". Metaphor involves deep cognitive processing and activation of encyclopedic knowledge as the understanding background and is employed by us as strategies to connect concepts other than just a linguistic event. In L2 learning process, leaners would resort to the L1's cognitive system and background encyclopedic knowledge unconsciously and continuously. In order to find out how much of L2 metaphoric competence could be accounted by L1 metaphoric competence, we carried out a regression analysis on the four scores. The results are presented below in Table 5 .

Table 5. Regression analysis of Chinese and English four respective scores

\begin{tabular}{llllc}
\hline & $\mathrm{R}^{2}$ & standard coefficient & $\mathrm{t}$ & Sig. \\
\hline ES-CS & 0.733 & 0.729 & 3.709 & .000 \\
EA-CA & 0.729 & 0.856 & 4.925 & .000 \\
EI-CI & 0.488 & 0.698 & 1.341 & .000 \\
EP-CP & 0.338 & 0.581 & 1.564 & .000 \\
\hline
\end{tabular}

Table 5 indicates that Chinese metaphoric competence could significantly account for that of English $(p<0.01)$. To be specific, Chinese metaphor recognition speed holds the highest accountability for English recognition speed $\left(R^{2}=0.733\right)$; Then is the acceptability $\left(R^{2}=0.729\right)$; the third is the interpretation $\left(R^{2}=0.488\right)$; and the last is the production $\left(\mathrm{R}^{2}=0.338\right)$. That provides a stronger support for the inclusion of L1 in L2 teaching and curriculum design as we put forward above.

\section{Conclusion}

Our study arose out of the finding that even though metaphoric competence transfer was well-documented, but no systematic and multidimensional study on Chinese leaners of English has been found yet. We hope that our data could supply more evidence across languages to contribute to the study of metaphoric competence transfer between L1 and L2. To this end, we redefined a framework for metaphoric subcompetences and designed an E-Prime-based experiment and two written tests on Chinese intermediate learners of English to find the 
differences and similarities between their L1 and L2 metaphoric competencies in the four dimensions. The results showed that there were statistically significant differences between L1 and L2 metaphoric competence in the four subcomponents for Chinese intermediate-level leaners of English, and that Chinese English learners' L2 metaphoric competence is statistically significantly correlated to the L1 metaphoric competence in the four subcomponents, and the regression analysis further confirms a significant transfer of L1 metaphoric competence to L2. The study enlightens us to integrate L1 into L2 teaching programs and to help students build cross-linguistic transfer ability in metaphoric competence. The study also provides data from Chinese English learners to enrich the metaphoric competence study across languages. It is hoped that this study could contribute to the study in the field of second language acquisition and other fields like translation and natural language processing. In the future, we hope to check our findings in more languages and from more levels of language proficiencies.

\section{Acknowledgments}

This paper is funded by the key project of Humanities and Social Sciences of Guangdong Province "Research on the Formal Representation and Cognitive Computation of Chinese Metaphors" (Approval No.: 2019WZDXM021), and the Research Fund for Doctoral Program of Xi'an International Studies University "An Integrated Analysis of Chinese Education Metaphors Based on MIPVU" (BSYJ201805).

\section{References}

Andreou, G., \& Galantomos, L. (2009). Conceptual competence as a component of second language fluency. Journal of Psycholinguist Research, 38, 587-591. https://doi.org/10.1007/s10936-009-9122-6

Azuma, M. (2004). Metaphorical competence in an EFL context: the mental lexicon and metaphorical competence of Japanese EFL students. PhD Dissertation, University of Nottingham.

Birdsell, B. J. (2018). Conceptual wandering and novelty seeking: Creative metaphor production in an L1 and L2. Journal of Cognitive Linguistics, 1, 35-67.

Bobrova, L. (2017). Enhancing metaphorical competence in the L2 Russian classroom. Journal of the National Council of Less Commonly Taught Languages, 22, 133-157.

Bromberek-Dyzman, K., \& Ewert, A. (2010). Figurative competence is better developed in L1 than in L2, or is it? Understanding conversational implicatures in L1 and L2. In M. Putz \& L. Sicola (Eds.), Cognitive processing in second language acquisition: Inside the learner's mind (pp. 317-334). Amsterdam/Philadelphia: John Benjamins Publishing Company. https://doi.org/10.1075/celcr.13.21bro

Chen, Y., \& Lai, H. (2015). Developing EFL Learners' metaphoric competence through cognitive-oriented methods. International Review of Applied Linguistics in Language Teaching, 4, 415-438. https://doi.org/10.1515/iral-2015-0019

Cook, V. J. (2013). Multicompetence. In C. A. Chappelle (Ed.), The encyclopedia of applied linguistics. Malden, MA: Wiley-Blackwell. https://doi.org/10.1002/9781405198431.wbeal0778

Danesi, M. (1986). The role of metaphor in second language pedagogy. Rassegna Italiana di Linguistica Applicata, 3, 1-10.

Danesi, M. (2003). Second Language Teaching: A View from the Right Side of the Brain. Dordrecht: Kluwer Academic Publishers. https://doi.org/10.1007/978-94-010-0187-8

Danesi, M. (2008). Conceptual errors in second language learning. In S. De Knop \& T. De Rycker (Eds.), Cognitive approaches to pedagogical grammar (pp. 231-257). Berlin/New York: Mouton de Gruyter.

Deignan, A. (2001). Metaphor. Beijing: Foreign Language Press.

Evans, V., \& Green, M. (2006). Cognitive linguistics: An introduction. Edinburgh: Edinburgh University Press.

Fauconnier, G., \& Turner, M. (1998). Conceptual integration networks. Cognitive Science, 22(2), 133-187. https://doi.org/10.1207/s15516709 $\operatorname{cog} 2202 \_1$

Flahive, D., \& Carrell, P. (1977). Lexical expansion and the acquisition of metaphoric competence. 11th Annual Mid-America Linguistics Conference. Columbia: University of Missouri.

Galantomos, I. (2019). Gender and proficiency effects on metaphor use among Greek learners. International Journal of Applied Linguistics, 1, 1-31. https://doi.org/10.1111/ijal.12238

García, O., \& Li Wei. (2014). Translanguaging: Language, bilingualism and bilingual education. Basingstoke, UK: Palgrave Macmillan. https://doi.org/10.1057/9781137385765 
Gardener, H., \& Winner, E. (1978). The development of metaphoric competence: Implications for humanistic disciplines. Critical Inquiry, 1, 123-141. https://doi.org/10.1086/447976

Haim, O. (2015). Investigating transfer of academic proficiency among trilingual immigrant students: A holistic tri-directional approach. The Modern Language Journal, 99(4), 696-717. https://doi.org/10.1111/modl.12278

Hoang, H., \& Boers, F. (2018). Gauging the association of EFL learners' writing proficiency and their use of metaphorical language. System, 74, 1-8. https://doi.org/10.1016/j.system.2018.02.004

Hoffman, R., \& Kemper, S. (1987). What could reaction-time studies be telling us about metaphor comprehension? Metaphor and Symbolic Activity, 2(3), 149-186. https://doi.org/10.1207/s15327868ms0203_1

Jiang, M., \& Wu, W. Y. (2017). Chinese English learners' implicit conceptual transfer in English sentence comprehension. Foreign Language Education, 38(3), 68-73.

Johnson, J. (1989). Factors related to cross-language transfer and metaphor interpretation in bilingual children. Applied Psycholinguistics, 10, 157-177. https://doi.org/10.1017/S014271640000850X

Johnson, J. (1996). Metaphor interpretations by second language learners: Children and adults. The Canadian Modern Language Review, 53(1), 219-241. https://doi.org/10.3138/cmlr.53.1.219

Johnson, J., \& Rosano, T. (1993). Relation of cognitive style to metaphor interpretation and second language proficiency. Applied Psycholinguistics, 14, 159-175. https://doi.org/10.1017/S014271640000953X

Kathpalia, S. S., \& Carmel, H. L. (2011). Metaphorical competence in ESL student writing. RELC Journal, 42(3), 273-290. https://doi.org/10.1177/0033688211419379

Littlemore, J. (2001). Metaphoric competence: A language learning strength of students with a holistic cognitive style? TESOL Quarterly, 3, 459-491. https://doi.org/10.2307/3588031

Littlemore, J. (2010). Metaphoric competence in the first and second language: Similarities and differences. In M. Putz \& L. Sicola (Eds.), Cognitive processing in second language acquisition: Inside the learner's mind (pp. 293-315). Amsterdam/Philadelphia: John Benjamins Publishing Company. https://doi.org/10.1075/celcr.13.20lit

Liu, Y. J. (2012). The empirical study on metaphorical understanding competence of second language under Chinese context. Computer-Assisted Foreign Language Education, 146, 75-80.

Low, G. (1988). On teaching metaphor. Applied Linguistics, 2, 125-147. https://doi.org/10.1093/applin/9.2.125

Martinez, F. (2003). Exploring Figurative Language Proficiency in Bilinguals: The Metaphor Interference Effect. Graduate Thesis, Texas A \& M University.

Odlin, T. (1989). Language Transfer: Cross-linguistic Influence in Language Learning. Cambridge: Cambridge University Press. https://doi.org/10.1017/CBO9781139524537

Pollio, H., \& Smith, M. (1980). Metaphoric competence and complex human problem solving. In R. Honeck \& R. Hoffman (Eds.), Cognition and Figurative Language (pp. 365-392). Hillsdale: Erlbaum Press. https://doi.org/10.4324/9780429432866-15

Shi, J. F. (2012). Developmental connections among L1 conceptual transfer competence, metaphoric competence and English proficiency. Foreign Language Learning Theory and Practice, 3, 57-63.

Strapparava, C. (2018). Metaphor: A computational Perspective. Computational Linguistics, 44(1), 1-2. https://doi.org/10.1162/COLI_r_00311

Trosborg, A. (1985). Metaphoric productions and preferences in second language learners. In W. Paprotté \& R Dirven (Eds.), The ubiquity of metaphor (pp. 525-557). Amsterdam: John Benjamins. https://doi.org/10.1075/cilt.29.20tro

Wang, Y., \& Li, H. (2004). An integrative pedagogy with language competence, communicative competence and metaphoric competence-The application of CMT in foreign language education. Journal of Sichuan International Studies University, 20(6), 140-143.

Wang, X. L., \& Wang, Y. Z. (2019). Restrictions of L1 transfer on the EFL learners' metaphor output-take Chinese non-English majors' English writing as an example. Foreign Language Education, 40(4), 56-63.

Wei, Y. Z. (2007). An Investigation into the Roles of Cognitive Ability and Language Proficiency in Chinese EFL 
Learners' Metaphor Comprehension and Production. PhD Dissertation, Shanghai Jiaotong University.

Yang, L. R., \& Xuan, F. F. (2012). Research on second language writing from the perspective of metaphor transfer of native language. Journal of Ocean University of China (Social Sciences), 3, 110-115.

Ye, D. (2015). The effects of L1 conceptual transfer competence on the metaphoric processing. Journal of Hubei University of Education, 32(5), 31-33.

Zamari, Z. M., Adnan, A. H. M., Manan, N. A. A., \& Pillay, I. A. S. (2016). A Comparative study of metaphoric competence in Malay and English with special focus on color-themed Idiomatic expressions (pp. 1-10). International Language and Tourism Conference.

Zhang, Y. (2019). The effect of metaphorical competence on students' writing skills. Creative Education, 10, 151-155. https://doi.org/10.4236/ce.2019.101011

\section{Copyrights}

Copyright for this article is retained by the author, with first publication rights granted to the journal.

This is an open-access article distributed under the terms and conditions of the Creative Commons Attribution license (http://creativecommons.org/licenses/by/4.0/). 